\title{
A novel pathogenic mutation of the CYP27B1 gene in a patient with vitamin D-dependent rickets type 1: a case report
}

Amir Ml Babiker ${ }^{1,2,5^{*}}$, Iman Al Gadi ${ }^{1,2}$, Nasir AM Al-Jurayyan ${ }^{1,2}$, Abdulrahman MH Al Nemri ${ }^{1}$, Ali Abdu N Al haboob ${ }^{1}$, Ahmed Amer Al Boukai ${ }^{3}$, Ali Al Zahrani ${ }^{4}$ and Hanan Ahmed Habib ${ }^{4}$

\begin{abstract}
Background: Rickets can occur due to Vitamin D deficiency or defects in its metabolism. Three rare genetic types of rickets with different alterations of genes have been reported, including: Vitamin D dependent rickets type 1, Vitamin D dependent rickets type 2 or also known as Vitamin D resistant rickets and 25 hydroxylase deficiency rickets. Vitamin D dependent rickets type 1 is inherited in an autosomal recessive pattern, and is caused by mutations in the CYP27B1 gene encoding the 1a-hydroxylase enzyme. We report here a new mutation in CYP27B1, which lead to Vitamin D dependent rickets type 1.
\end{abstract}

Case presentation: We report on a 13-month-old Arabic Saudi girl with Vitamin D dependent rickets type 1 presented with multiple fractures and classic features of rickets. A whole exome sequencing identified a novel pathogenic missense mutation (CYP27B1:Homozygous c.1510C > T(p.Q504X)) which results in a protein truncating alteration. Both parents are heterozygous carriers of the mutation. Based on data search in Human Gene Mutation Database, 63 CYP27B1 alterations were reported: only $28.6 \%$ are protein truncating (5 nonsense, 13 frameshift insertions/deletions, 0 gross deletions), while 61.9\% are non-truncating (38 missense, 1 small in-frame insertions/deletion), and 9.5\% are possible protein-truncating (5 splice, 1 regulatory).

Conclusion: The deleterious effect of this alteration, which was the only mutation detected in the CYP27B1 common gene of Vitamin D dependent rickets type 1 in the proband, and its autosomal recessive inheritance fashion, both support a pathogenic nature of this mutation as the cause of Vitamin D dependent rickets type 1.

Keywords: CYP27B1, 1,25 dihydroxyvitamin D3, Missense mutation, Rickets, Saudi Arabia, VDDR-1

\section{Background}

Vitamin D, whether synthesized in the skin or obtained from the diet, is biologically inert and requires activation via two selective metabolic steps; the second of them is rate-limiting and hormonally regulated (Figure 1). Both of the steps are catalyzed by cytochrome P450 enzymes to form the active secosteroid hormone 1,25 dihydroxyvitamin D3 $\left(1,25(\mathrm{OH})_{2} \mathrm{D} 3\right)[1,2]$.

Vitamin D deficiency remains the commonest cause of rickets worldwide [3,4]. So far, apart from liver or renal

\footnotetext{
* Correspondence: babikeramir@hotmail.com

'Pediatric Department, College of Medicine and King Khalid University

Hospital, Riyadh, Saudi Arabia

${ }^{2}$ Pediatric Endocrine Division, King Khalid University Hospital and King Saud

University, Riyadh, Saudi Arabia

Full list of author information is available at the end of the article
}

diseases that may affect vitamin D metabolism, three rare genetic errors of vitamin $\mathrm{D}$ metabolism that can cause rickets have been described [3-6]. The first involves $1 \alpha$-hydroxylase deficiency, also described as vitamin D dependent rickets type 1 (VDDR-1). The second type involves defective vitamin $\mathrm{D}$ receptor (VDR), resulting in vitamin $\mathrm{D}$ resistant rickets (VDRR), also known as vitamin D dependent rickets type II (VDDR II) [3]. More rare, 25 hydroxy vitamin D3 (25OHD3) deficiency have been reported and linked to a selective mutation in CYP2R1 gene that leads to 25-hydroxylase deficiency [4,5].

Children with VDDR-1 may present with hypotonia, muscle weakness, joint pain and deformity, growth failure, seizures, or fractures in early infancy [3]. We report a 13-month-old girl with VDDR-1 presented with multiple 


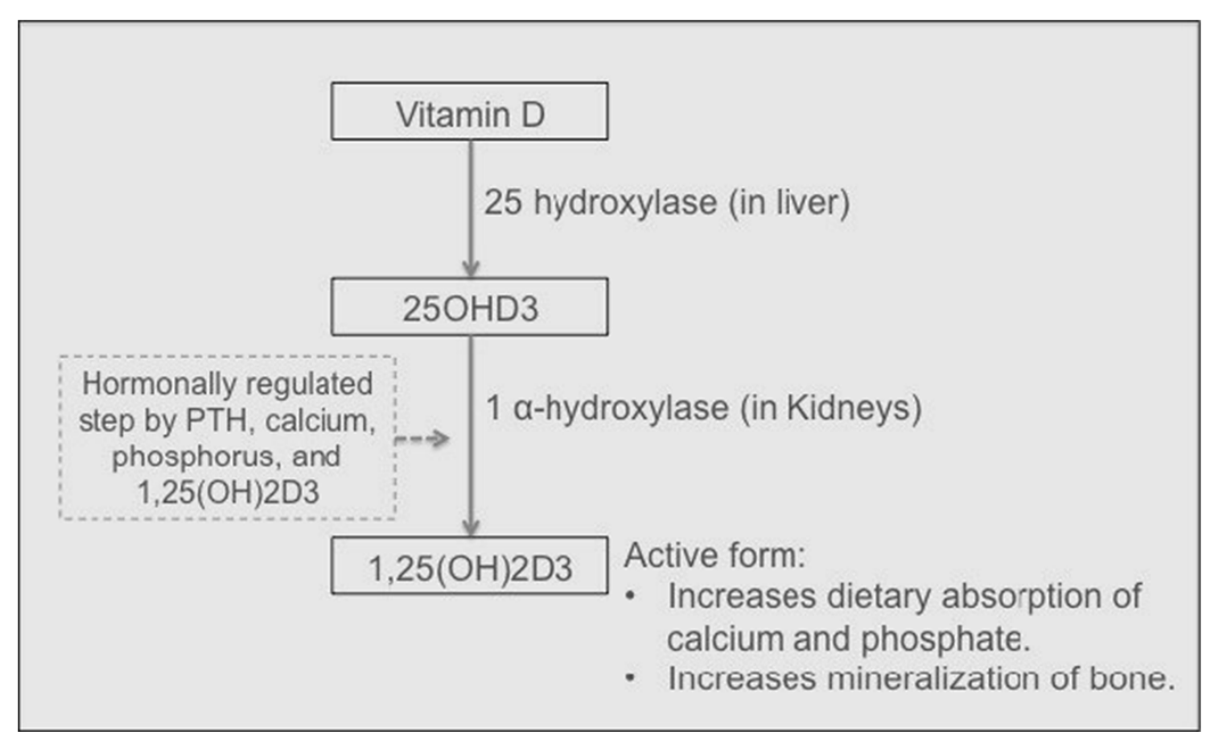

Figure 1 Bio-activation pathway of vitamin D.

fractures, classic biochemical and severe radiological findings of rickets. An initial CYP27B1 gene analysis for common alterations was performed and showed no diseaseassociated mutations in this patient. However, the whole exome sequencing identified a novel pathogenic mutation (CYP27B1: Homozygous c.1510C > T(p.Q504X)) in our patient.

\section{Case presentation}

A 13-month-old Arabic Saudi girl, previously well, presented with multiple fractures as a result of minor traumas. She was adequately exposed to sunlight and had normal perinatal, developmental, and nutritional history. She is the only child for first-cousins parents, with no family history of similar problems or metabolic bone disease. Examination revealed normal growth for age, mildly reduced muscle tone, normal teeth, rachitic rosary, Harrison's sulcus, widening of the wrist and bowing deformity of distal arms and legs. Her head circumference was on the 50th centile for age with a frontal bossing and wide anterior fontanel. She had a swelling, secondary to fracture, over her right clavicle. However, the rest of her skin examination was normal and no other signs, which might suggest physical abuse. Initial investigations showed: low serum calcium and phosphorus, high serum parathyroid hormone (PTH), high serum alkaline phosphatase, a normal serum 25OHD3 which was repeated two times, and inappropriately low normal serum $1,25(\mathrm{OH})_{2} \mathrm{D} 3$ suggesting $1 \alpha$-hydroxylation defect (Table 1). Radiological workup showed generalized osteopenia with multiple fractures involving the right clavicle, right ulna, left proximal ulna and tibia bones. Disorganization of the growth plate was apparent with classic features of rickets (Figure 2).
In the light of the above biochemical results and severe radiological findings, genetic types of rickets were suspected. Initially, CYP27B1 gene analysis was performed only for the common mutations in exon 2 and 8 and it was negative. Unfortunately, the genetic laboratory, where the common mutations of CYP27B1 gene tests were tested, did not offer further analysis of the same common gene. Alternatively, It was suggested to perform mutations analysis for hypophosphataemic rickets but this was clinically and biochemically irrelevant in this patient. With a high clinical suspicion of $1 \alpha$-hydroxylation defect, a whole exome sequencing test was performed in another genetic lab, with a report of a likely diagnosis of VDDR-1 (MIM-609506). The exome sequencing revealed a novel pathogenic nonsense deleterious mutation in the proband's CYP27B1 gene (CYP27B1: Homozygous c.1510C > T (p.Q504X)), with both parents found to be heterozygous carriers of the mutation (Table 2).

Awaiting the genetic results, the patient required high doses of $1 \alpha$-hydroxyvitamin D and calcium supplements to heal her bones and to return serum chemistries to normal (Table 1).

\section{Discussion}

CYP27B1 gene is located on chromosome 12q13.3. It encodes a member of the cytochrome P450 superfamily of enzymes, which are monooxygenases that catalyze many reactions involved in drug metabolism and synthesis of cholesterol, steroids and other lipids. CYP27B1 gene encodes $1 \alpha$-hydroxylase enzyme that is localized to the inner mitochondrial membrane of renal cells; in which it activates $25 \mathrm{OHD} 3$ to synthesise $1,25(\mathrm{OH})_{2} \mathrm{D} 3$, which binds to vitamin $\mathrm{D}$ receptor and regulates calcium 


\section{Table 1 Biochemical laboratory results of the patient in relation to time and treatment}

\begin{tabular}{|c|c|c|c|c|c|c|c|}
\hline $\begin{array}{l}\text { Time (At presentation } \\
\text { and afterwards) }\end{array}$ & $\begin{array}{c}\text { Serum } 25 \mathrm{OHD} 3 \\
{[\mathrm{~N}=75-250 \mathrm{nmol} / \mathrm{L}]}\end{array}$ & $\begin{array}{l}\text { Serum } 1,25(\mathrm{OH})_{2} \mathrm{D} 3 \\
{[\mathrm{~N}=15-75 \mathrm{pg} / \mathrm{mL}]}\end{array}$ & $\begin{array}{c}\text { Serum PTH } \\
{[\mathrm{N}=1.65-6.9 \mathrm{pmol} / \mathrm{L}]}\end{array}$ & $\begin{array}{c}\text { Serum Calcium } \\
{[\mathrm{N}=2.25-2.75 \mathrm{mmol} / \mathrm{L}]}\end{array}$ & $\begin{array}{c}\text { Serum Phosphorus } \\
{[\mathrm{N}=1.45-2.16 \mathrm{mmol} / \mathrm{L}]}\end{array}$ & $\begin{array}{l}\text { Serum Alkaline phosphatase } \\
{[\mathrm{N}=175-476 \mathrm{IU} / \mathrm{L}]}\end{array}$ & $\begin{array}{l}\text { Serum Magnesium } \\
{[\mathrm{N}=0.7-1.1 \mathrm{mmol} / \mathrm{L}]}\end{array}$ \\
\hline \multirow[t]{2}{*}{ At presentation } & 119.5 & 16 & 52.9 & 1.94 & 0.82 & 1682 & 0.7 \\
\hline & $\begin{array}{l}\text { Treatment: She was } \mathrm{s} \\
\text { monitoring of serum } 1\end{array}$ & $\begin{array}{l}\text { tarted with high-dose } \\
\text { evels }\end{array}$ & 1a-hydroxyvitamin D3 & 000 IU/day) and elemental & calcium (61 mg/kg/day), & it was gradually increased to 1 & $50 \mathrm{mg} / \mathrm{kg} /$ day with \\
\hline \multirow[t]{2}{*}{1 month } & 99.9 & - & 54.9 & 1.90 & 0.86 & 2027 & - \\
\hline & Treatment: Addition & of oral phosphate supp & lements. She developed & diarrhoea, so it was stopp & bed after 1 week & & \\
\hline \multirow[t]{2}{*}{2 months } & 99.3 & - & 55.4 & 1.6 & 0.90 & 1276 & - \\
\hline & Treatment: Continuec & d on 1a-hydroxyvitamin & D3 (2000 IU/day) and $h$ & igh-dose of calcium suppl & lements (up to $200 \mathrm{mg} / \mathrm{kg}$ & /day) & \\
\hline \multirow[t]{2}{*}{3 months } & - & - & $\begin{array}{l}\text { Initially } 14.00 \text { then } \\
\text { back to } 21.36\end{array}$ & 2.06 & 1.02 & 1358 & - \\
\hline & Treatment: Started to & wean off 1a-hydroxyvi & tamin D3. The PTH went & thigh again, so it was initi & ial dose was resumed agai & in (2000 IU/day). & \\
\hline 6 months & - & - & 21.41 & 2.19 & 1.41 & 503 & - \\
\hline \multirow[t]{2}{*}{9 months } & - & - & 0.97 & 2.44 & 1.94 & 233 & - \\
\hline & Treatment: 1a-hydrox & yyvitamin D3 was wean & ed off gradually down tc & o (1200 IU/day), with calciu & um supplements (100 mg/ & /kg/day) & \\
\hline \multirow[t]{2}{*}{10 months } & - & - & 0.63 & 2.29 & 2.11 & 222 & 0.7 \\
\hline & Treatment: Daily Dose & es settled on 1a-hydrox & yvitamin D3 (800 IU/day & ) and Calcium supplement & tts (80 mg/kg/day) & & \\
\hline
\end{tabular}

1,25(OH)2D3- 1,25 dihydroxyvitamin D3, 25OHD3- 25-hydroxyvitamin D3, and PTH- Parathyroid hormone. 

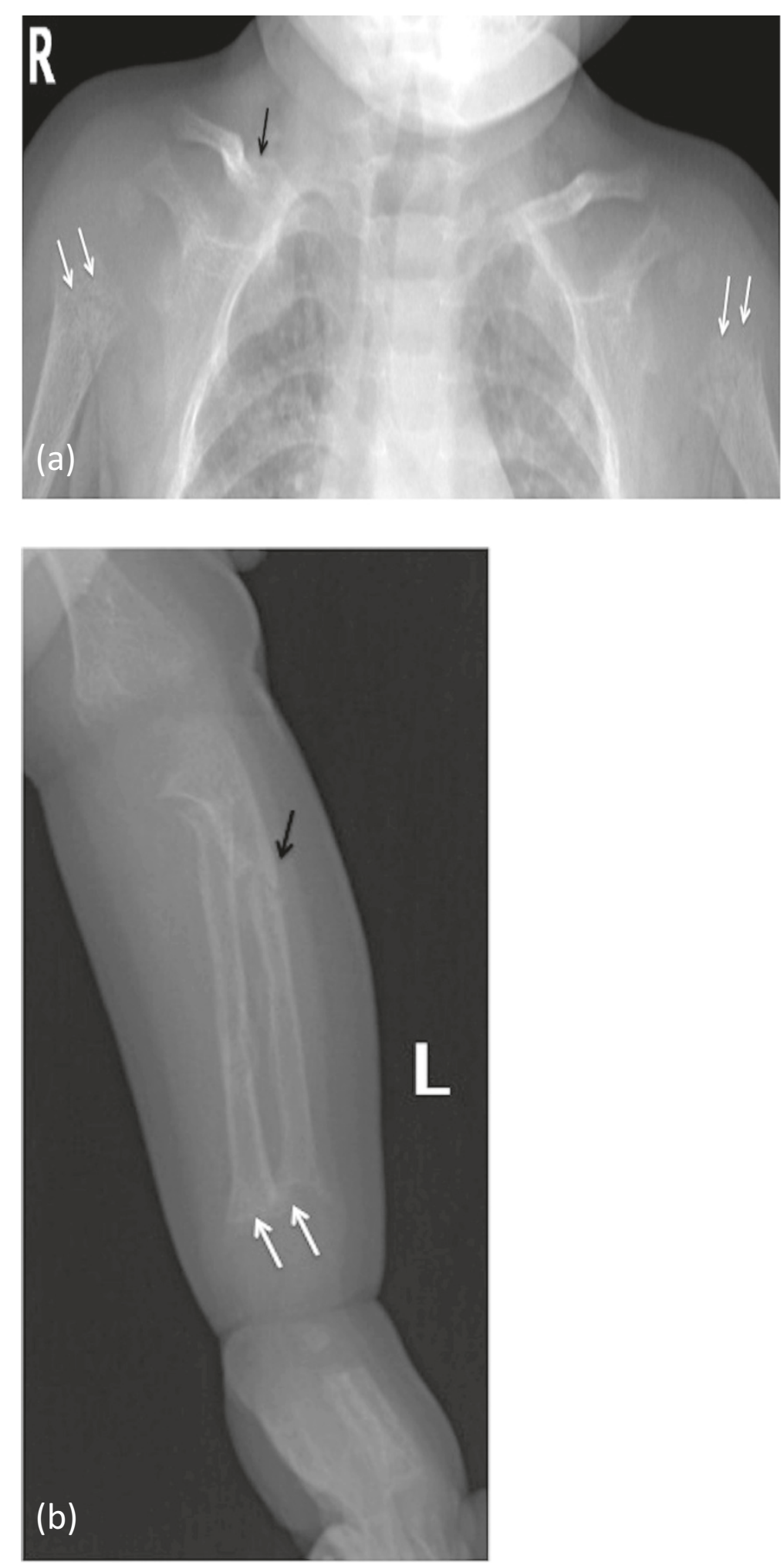

Figure 2 X-ray images at time of presentation showing generalized osteopenia with altered texture (a \& b). Humeral metaphysis shows frying with more pronounced lucency (a), and ulnar/radial metaphysis shows frying and cupping of their outline (b) - (white arrows). The cortices are indistinct with coarse fuzzy trabecuale (a \& b). Fracture of right clavicle (a), and proximal shaft of the ulna (b) - (black arrows). 
Table 2 Familial co-segregation analysis of the proband

\begin{tabular}{lllllll}
\hline Gene(s) & Filtering model & Location of alteration & Alteration & Proband & Mother & Father \\
\hline CYP27B1 & Autosomal recessive & 12 113.1-q13.3 & c.1510C > T(p.Q504X) & Homozygous & Heterozygous & Heterozygous \\
\hline
\end{tabular}

metabolism. Homozygous or compound heterozygous alterations in this gene are inherited in autosomal recessive pattern, and are in association with VDDR-1 [7].

In our patient, the clinical, biochemical and radiological findings were all consistent with those of previously reported patients with CYP27B1 gene alterations $[3,8]$. The first reported negative result of genetic mutations suggestive of VDDR-1 was based on inadequate examination, only for the common alterations in exons 2 and 8 of CYP27B1. This, beside the suggestion of further testing for hypophosphataemic rickets by the genetic lab, which was clinically irrelevant in our patient, both had mislead the directions of choice for further genetic testing. It would have been reasonable to perform a full analysis of the CYP27B1 gene alone for any other mutations in the first place, which could have detect the novel mutation in our patient, before proceeding for a whole exome sequencing in this patient. Nonetheless, genetic analysis with full exome sequencing, bioinformatics analysis and filtering based on autosomal and X-linked dominant and recessive inheritance models of the proband, mother, and father revealed 53 genes (70 unique alterations) (Table 3). Manual review to rule out sequencing artefacts and polymorphisms along with the medical interpretation to rule out genes lacking clinical overlap with the patient's evaluated phenotype resulted in 25 genes (36 unique alterations) (Table 3).

Alterations with likely clinical relevance "candidate genes" underwent co-segregation analysis, in which 1 candidate gene (1 alteration): (CYP27B1:Homozygous
c.1510C > T(p.Q504X)) was selected for further investigations. The familial co-segregation analysis sustained the significance of the identified gene alteration, and revealed an inheritance fashion of the mutation as both parents were found to be heterozygous carriers of the alteration (Table 2).

This identified novel CYP27B1 alteration displayed a deleterious nature and it is the likely cause of our patient's clinical findings. This is implemented by: Firstly, the premature protein truncation effect of the alteration. The $c .1510 C>\mathrm{T}(\mathrm{p} . \mathrm{Q} 504 \mathrm{X})$ alteration results from a $\mathrm{C}$ to $\mathrm{T}$ nucleotide substitution at position 1510 . This changes an amino acid from a glutamine to a stop codon; and premature stop codons are typically deleterious in nature [9-11]. Secondly, the inconsistency of the alteration type with the previously reported predominant CYP27B1 alterations. Based on data search in the Human Gene Mutation Database (HGMD), 63 CYP27B1 alterations were reported: only $28.6 \%$ are protein truncating (5 nonsense, 13 frameshift insertions/deletions, 0 gross deletions), while $61.9 \%$ are non-truncating (38 missense, 1 small in-frame insertions/deletion), and 9.5\% are possible protein-truncating (5 splice, 1 regulatory) [12]. Thirdly, the inheritance pattern of the detected alteration in our patient is consistent with an autosomal recessive fashion.

\section{Conclusion}

The deleterious nature of the reported novel CYP27B1: c.1510C > T(p.Q504X) alteration and its inheritance fashion

Table 3 Full exome-sequencing results of the patient

\begin{tabular}{|c|c|c|c|c|c|c|}
\hline \multicolumn{7}{|c|}{ Variant filtering based on inheritance model, clinical and bioinformatics analysis } \\
\hline & \multirow{3}{*}{$\begin{array}{l}\text { Post-inheritance } \\
\text { model filtering }\end{array}$} & \multirow{3}{*}{$\begin{array}{c}\text { Post-alteration } \\
\text { review } \\
\text { Total }\end{array}$} & \multicolumn{3}{|c|}{ Post-medical review } & \multirow{3}{*}{$\begin{array}{c}\text { Candidate } \\
\text { genes }\end{array}$} \\
\hline & & & \multicolumn{3}{|c|}{ Post-clinical associated review } & \\
\hline & & & Characterized & Clinically novel & Total & \\
\hline Autosomal dominant genes (alterations) & $12(13)$ & 2(2) & $0(0)$ & $1(1)$ & 1(1) & $0(0)$ \\
\hline Autosomal recessive genes (alterations) & $41(57)$ & $32(45)$ & $1(1)$ & 23(34) & 24(35) & $1(1)$ \\
\hline X-linked recessive genes (alterations) & $0(0)$ & $0(0)$ & $0(0)$ & $0(0)$ & $0(0)$ & $0(0)$ \\
\hline X-linked dominant genes (alterations) & $0(0)$ & $0(0)$ & $0(0)$ & $0(0)$ & $0(0)$ & $0(0)$ \\
\hline Y-linked genes (alterations) & N/A & N/A & N/A & N/A & N/A & N/A \\
\hline Total genes (alterations) & $53(70)$ & $34(47)$ & $1(1)$ & 24(35) & 25(36) & $1 *(1)$ \\
\hline
\end{tabular}

*The candidate gene in this patient is CYP27B1 gene, which is located in chromosome 12q13.3 and encodes a member of the cytochrome P450 superfamily of enzymes. The cytochrome P450 proteins are monooxygenases, which catalyze many reactions involved in drug metabolism and synthesis of cholesterol, steroids and other lipids. The protein encoded by this gene localizes to inner mitochondrial membrane where it hydroxylates 25 -hydroxyvitamin D3 at the 1 alpha position. This reaction synthesizes 1, 25 dihydroxyvitamin D3, which binds to vitamin D receptor and regulates calcium metabolism. Thus this enzyme regulates the level of biologically active vitamin $\mathrm{D}$ and plays a major role in calcium homeostasis. Mutations in this gene can result in vitamin $\mathrm{D}$ dependent rickets type 1 . 
in our patient supports its classification as a pathogenic mutation for VDDR-1.

\section{Consent}

Ethical approval for this study was obtained from the ethics committee at King Khalid University Hospital, and parents consented to genetic testing and consented to genetic testing in their child. Copies of the written consents are available for review by the Editor-in-Chief of this journal.

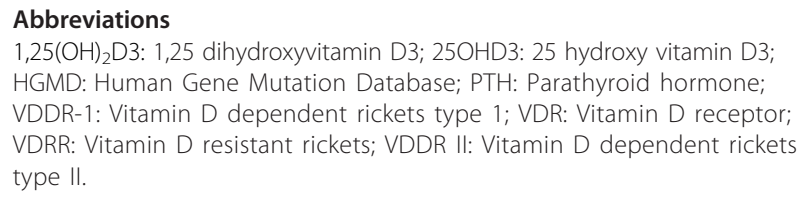

\section{Competing interests}

The authors declare that they have no competing interests.

\section{Authors' contributions}

Idea conceived by $\mathrm{AB}$ - The main author and treating consultant of the patient in the case report. AB, IG and NJ - Contributed in patient's management as well as writing and drafting the manuscript, IG - also designed Figure 1. ABO, AN, AAA, $\mathrm{HH}$ and AA - Contributed in patient's management as well as arranging and interpreting the biochemical, genetic and radiological findings in this patient, $\mathrm{ABO}$ - also reported the findings in Figure 2 and put ligands for it. All authors approved the final format of the submitted manuscript.

\section{Authors' information}

All of the authors in this article are currently employed by King Khalid University Hospital and King Saud University, Saudi Arabia. Amir Babiker (AB) is a Fellow of the Royal College of Paediatrics and Child Health. He is a Consultant Paediatric endocrinologist and Assistant Professor of Paediatrics. Iman Al Gadi (AG) is a Paediatric resident and demonstrator in Endocrine division (Paediatrics). Nasir A. Al Jurayyan (NAA), MD, is Professor of Paediatrics, Consultant Paediatric endocrinologist and Head of Endocrine division. Abdulrahman Al-Nemri (AA), MD, is Chairman of the Paediatric Department and Associate Professor of Paediatrics. Ali Abdu Haboob (AAA), MD, is a consultant Paediatric Intensivist and Assistant Professor of Paediatrics. Ahmed Amer Al Boukai (ABO), MD, FRKSU is an Associate Professor and Consultant Radiologist. Ali Al Zahrani (AA), a Technician in the Department of Pathology. Hanan Habib (HH), MD, is Professor of Pathology and a Consultant Pathologist.

\section{Acknowledgement}

The authors would like to thank and extend their appreciation to the College of Medicine Research Centre, Deanship of Scientific Research, King Saud University, Riyadh, Saudi Arabia for funding this work.

The authors would also like to acknowledge Professor Fowzan Al Kuraya, Head of Developmental Genetics Unit, King Faisal Specialist Hospital and Research Centre, College of Medicine, Alfaisal University, Riyadh, Saudi Arabia, for his kind efforts of reviewing the genetic results from the two labs, confirming the interpretation of the genetic results and helping us in searching the HGMD to confirm the novelty of this mutation.

\section{Author details}

${ }^{1}$ Pediatric Department, College of Medicine and King Khalid University Hospital, Riyadh, Saudi Arabia. ${ }^{2}$ Pediatric Endocrine Division, King Khalid University Hospital and King Saud University, Riyadh, Saudi Arabia. ${ }^{3}$ Radiology and Medical Imaging Department, King Khalid University Hospital and King Saud University, Riyadh, Saudi Arabia. ${ }^{4}$ Pathology Department, King Khalid University Hospital and King Saud University, Riyadh, Saudi Arabia. ${ }^{5}$ Pediatric Department, College of Medicine, King Khalid University Hospital and King Saud University, PO Box 2925, Riyadh 11461, Saudi Arabia.

Received: 24 August 2014 Accepted: 24 October 2014 Published: 5 November 2014

\section{References}

1. Hewison M, Zehnder D, Bland R, Stewart PM: 1 alpha-Hydroxylase and the action of vitamin D. J Mol Endocrinol 2000, 25:141-148.

2. Portale AA, Miller WL: Human 25-hydroxyvitamin D- 1 alpha-hydroxylase: cloning, mutations, and gene expression. Pediatr Nephrol 2000, 14:620-625.

3. Malloy PJ, Feldman D: Genetic disorders and defects in vitamin D action. Rheum Dis Clin North Am 2012, 38:93-106.

4. Allgrove J, Shaw N: Calcium and bone disorders in children and adolescents. In Endocrine Development. Volume 16. Basel: Karger AG; 2009.

5. Cheng JB, Levine MA, Bell NH, Mangelsdorf DJ, Russell DW: Genetic evidence that the human CYP2R1 enzyme is a key vitamin D 25-hydroxylase. Proc Natl Acad Sci 2004, 101(20):7711-7715.

6. Misra M, Pacaud D, Petryk A, Collett-Solberg PF, Kappy M, and on behalf of the Drug and Therapeutics Committee of the Lawson Wilkins Pediatric Endocrine Society: Vitamin D deficiency in children and its management: review of current knowledge and recommendations. Pediatrics 2008, 122(2):398-417.

7. RefSeq: The NCBI Handbook [homepage on the Internet]. Chapter 18, The Reference Sequence (RefSeq) Project. c2013. Bethesda (MD): National Library of Medicine (US), National Center for Biotechnology Information; 2002 [updated 2013 July 19; cited 2014 August 20] Available from: [http://www.ncbi.nlm.nih.gov/books/NBK21091/]

8. Wang JT, Lin CJ, Burridge SM, Fu GK, Labuda M, Portale AA, Miller WL: Genetics of vitamin D 1 alpha-hydroxylase deficiency in 17 families. Am $J$ Hum Genet 1998, 63(6):1694-1702.

9. Griffiths AJF, Miller JH, Suzuki DT, Lewontin RC, Gelbart WM: An Introduction to Genetic Analysis. 7th edition. New York: W. H. Freeman; 2000.

10. Culbertson MR: RNA surveillance. Unforeseen consequences for gene expression, inherited genetic disorders and cancer. Trends Genet 1999, 15(2):74-80

11. Wilkinson MF, Shyu AB: RNA surveillance by nuclear scanning? Nat Cell Biol 2002, 4(6):E144-E147.

12. Human Gene Mutation Database [homepage in the Internet]. [cited 2014 August 20] Available from: [http://www.hgmd.cf.ac.uk/]

\section{doi:10.1186/1756-0500-7-783}

Cite this article as: Babiker et al:: A novel pathogenic mutation of the CYP27B1 gene in a patient with vitamin D-dependent rickets type 1: a case report. BMC Research Notes 2014 7:783.

\section{Submit your next manuscript to BioMed Central and take full advantage of:}

- Convenient online submission

- Thorough peer review

- No space constraints or color figure charges

- Immediate publication on acceptance

- Inclusion in PubMed, CAS, Scopus and Google Scholar

- Research which is freely available for redistribution 